\title{
SMART GROWTH OF THE EUROPEAN UNION COUNTRIES IN THE CONTEXT OF EUROPE 2020 STRATEGY GOALS
}

\begin{abstract}
The article presents the results of research on the state of implementation of limited aspects of the European Union Europe 2020 Strategy. Based on the analysis of statistical data, the paper indicates possible scenario concerning the achievement of one of the most important Europe 2020 Strategy goal (level of R\&D expenditure). An attempt was also made to verify the thesis that there is a close relation between the level of expenditure on R\&D in relation to GDP and the competitiveness of a given economy. The findings lead to the conclusion that there is a positive correlation between expenditure on R\&D in relation to GDP in a given country and the competitive position of economies. However, weak dynamics of growth in outlays in R\&D field may result in failure to achieve the assumed indicators and thus worsen the competitive position of the EU countries in the global world.
\end{abstract}

Keywords: European Union, Europe 2020 Strategy, R\&D, innovation, competitiveness, economy.

\section{INTRODUCTION}

The end of the 20th century and the beginning of the 21st century is the period in the European Union (EU) of overcoming stagnation and facing new challenges in different dimensions: economic, political, social. These challenges forced the European Union leaders to undertake new, unconventional and ambitious actions. The development goals for the EU were defined in two strategic documents adopted during this period: the Lisbon Strategy (EU development program in 10-year period, which was adopted at the Lisbon European Council in March 2000) and in Europe 2020. The Strategy for smart, sustainable and inclusive growth (Europe 2020 Strategy). The implementation of the first one ended with the fiasco. The question about the chances of success of the other remains open. One of the common elements of both strategic documents was the emphasis on investments in the field of research and development (R\&D). These kind of investments were (and still are) perceived as the remedy for economic stagnation and for structural weaknesses of the EU. Moreover, support for R\&D sector is the core idea leading to socio-economic development of modern economies.

One of the main objectives of the Lisbon Strategy was to make the European Union the most competitive economy in the world. The method of reaching this ambitious goal was

\footnotetext{
${ }^{1}$ Daniel Dariusz Kotkowski, PhD; e-mail: dkotkowski@wp.pl. ORCID: 0000-0002-5963-0248.
} 
strengthening the research and development sector $(\mathrm{R} \& \mathrm{D})^{2}$ defined as a source of innovation and a prerequisite for economic development. The set up target was the level of investments in this area: $3 \%$ of the GDP of the European Union. Although the objective of the Lisbon Strategy was not achieved ${ }^{3}$ and the strategy itself was replaced by a new document (Europe 2020 Strategy), the significance of research and development activities that are to be reflected in the economic development of EU countries is still underlined ${ }^{4}$.

\section{GOAL AND METHOD}

The economic crisis of 2008-2009 which hit Member States in a severe way has not changed the introduction of new development paradigm of the EU. Moreover, the latest social and political processes, such as the migration crisis or the results of the referendum in Great Britain which determine the country's abandonment of the European Union, do not change it either. Nevertheless, the above mentioned processes may influence the EU economic policy coordination and de facto may undermine the legitimacy and feasibility of the strategic objectives set for the entire EU for 2020. Additionally, during the discussions concerning the EU financial perspective 2021-2027 there are no issues concerning strategic planning. One should rather expect a complete abandonment of the joint European Union strategy for the next period which will be covered by the Multiannual Financial Framework 2021-2027.

The aim of the article is to verify the feasibility of the objectives set in the Europe 2020 Strategy regarding the level of R\&D expenditure in relation to individual Member States and to the European Union as a whole. Additionally, it was examined whether and to what extent EU Member States followed the main EU strategic documents indicating that the source of economic growth and competitiveness is development of the R\&D sector (reflected in the increase in $R \& D$ expenditure). An attempt was also made to verify the thesis that there is a close relationship between the level of expenditure on $R \& D$ in relation to GDP and the competitiveness of a given economy. There were differentiated research methods applied. For the purpose of retrospective analysis of numerical data quantitative methods were applied allowing for ordering and aggregation of source data in accordance with required degree of detail. There were also applied statistical methods including statistical time series analysis.

\section{THE EUROPEAN UNION R\&D POLICY AT THE BEGINNING OF 21ST CENTURY}

The European Union policy in the field of R\&D has its foundation in the Treaty on the functioning of the European Union (Part III, Title XIX Research and technological development and space $)^{5}$. The document indicates that the main field of public intervention at

${ }^{2}$ For the purpose of analyses in this article, the R\&D sphere is understood as systematically conducted creative work, undertaken to increase the knowledge base, including knowledge about people, culture and society, as well as to find new applications for this knowledge.

${ }^{3}$ Commission staff working document. Lisbon Strategy evaluation document, Brussels, 02.02.2010, SEC (2010), 114, final.

4 The R\&D issue and the impact on economic development are also emphasized by D. Drabińska who undertaken researches on new paradigm in economic and social sciences (Drabińska, 2008).

5 According to Art. 179 "The Union shall have the objective of strengthening its scientific and technological bases by achieving a European research area in which researchers, scientific knowledge 
the EU level is the promotion of cross-border cooperation between scientists in order to create the European Research Area. This reflects the position that has been given to R\&D dimension in the context of the European Union.

Taking into account the documents aimed at smooth implementation of the Treaty two of them are especially important: the Lisbon Strategy (renewed in 2005) and the Europe 2020 Strategy. Additionally, there were adopted programmes which were aimed at facilitation of the research and development policy. The most important of them were Framework Programmes which from the beginning of their existence had been several times modified. However, the improvements did not eliminate the weaknesses of these instruments, including bureaucratic burdens, complex management and control rules not adapted to the specificity of the R\&D sphere, low level of private entities involvement and poor coordination at the EU level (Ferrer, Figueira, 2011). In the EU's financial perspective 2014-2020, the Framework Programmes were replaced by the EU Horizon 2020 Programme which was supposed to eliminate the weaknesses identified in the programmes implemented so far. The role of R\&D sphere has been systematically growing in the European Cohesion Policy mainly through intervention under the European Regional Development Fund and the European Social Fund. The Cohesion Policy financial support in the period 2014-2020 is strictly focused on those areas that are conducive to the implementation of the Europe 2020 Strategy ${ }^{6}$.

At the beginning of the 21 st century an attempt was made to give the policy in the field of R\&D (or the EU's innovation policy) more significant place than it had in the past. The European Council at the meeting in Lisbon in March 2000 adopted a strategic document setting targets for the European Union for a period of 10 years. The goal set was extremely ambitious - creating the EU the most competitive economic area developing faster than the USA. The main impulse for development was to be a knowledge-based economy. It was assumed that by 2010 expenditure on R\&D would reach the level of $3 \%$ of GDP. Despite modifications of the Lisbon Strategy in the middle of its implementation its objectives were not achieved and the EU's competitive position to the USA in fact has deteriorated. The R\&D expenditure ratio in 2010 reached $2 \%$ of the GDP of the European Union (the Lisbon Strategy goal was not met).

The European Council on 26 March 2010 adopted the proposal for launching a new strategy for growth and high quality employment policy ${ }^{7}$. It emphasised sustainable and inclusive growth as a method to overcome the structural weaknesses in Europe's economy. The framework for its implementation was determined by the integrated guidelines for eco-

and technology circulate freely, and encouraging it to become more competitive, including in its industry, while promoting all the research activities deemed necessary by virtue of other Chapters of the Treaties".

${ }^{6}$ Art. 18 of Regulation (EU) No 1303/2013 of the European Parliament and of the Council of 17 December 2013 laying down common provisions on the European Regional Development Fund, the European Social Fund, the Cohesion Fund, the European Agricultural Fund for Rural Development and the European Maritime and Fisheries Fund and laying down general provisions on the European Regional Development Fund, the European Social Fund, the Cohesion Fund and the European Maritime and Fisheries Fund and repealing Council Regulation (EC) No 1083/2006 (OJ L 347, 20.12.2013).

${ }^{7}$ Communication from the Commission, Europe 2020. A strategy for smart, sustainable and inclusive growth, Brussels, 3.3.2010, $\operatorname{COM}(2010) 2020$ final. 
nomic $^{8}$ and employment policy ${ }^{9}$. Guideline 4 referred directly to the R\&D sphere and indicated actions to be taken at national and at the EU level in the field of research, development and innovation. What should be emphasized is the goal for the EU and in principle a return to the Lisbon Strategy indicator which was the basis for determining national targets. It was an increase in expenditure on investment in research and development up to $3 \%$ of the Union's GDP by 2020. As emphasized in the document, this is to be an indicator of the increasing intensity of R\&D and innovation.

In order to avoid failure as was the case with the Lisbon Strategy indirect objectives and recommendations to achieve the goals were formulated more precisely. The document specifying the objectives is "Europe 2020 flagship initiative. Innovation Union" ${ }^{10}$. The document explicitly indicates that investing in $R \& D$ is to be a way to raise the EU's competitiveness and a method for smart growth. It also referred to the difficult economic situation of many Member States indicating the necessary actions to be undertaken. It was stated that despite the EU financial constraints Member States should continue to invest in education, research and development, innovation and ICT. If possible, it should not only protect such investments from budget cuts but also increase their scale. Thus, it was clearly stated that expenditures on R\&D sphere are on the one hand a specific panacea for the crisis and an element that allows to overcome it and on the other hand - a source of competitiveness of the entire EU in the global world.

R\&D policy is gaining more and more importance in the EU which is reflected in the main strategic documents. Nevertheless, in the above-mentioned context one should ask a question about the basis for objective specified so precisely in the strategic documents for the objective ( $3 \%$ of GDP on R\&D) and whether it is feasible to achieve it bearing in mind the tendencies in financing this sphere at the beginning of the 21 st century. Statistical data, the list and analysis of which can be found later in this article, may be helpful in answering these additional questions.

\section{ANALYSIS OF THE EU MEMBER STATES' LEVEL OF EXPENDITURE ON RESEARCH AND DEVELOPMENT (R\&D)}

The EU strategic documents clearly indicate that innovation is the source of economic growth. The main mode for increasing innovativeness of the economies is to strengthen research and development (R\&D) (Aghion, 2006). The indicator for assessment of the importance of $R \& D$ sector is the level of expenditure on $R \& D$. It also enables to assess whether we can think about a knowledge-based economy. According to A. Kukliński in knowledge-based economy this level should not be less than $2.5 \%$ of GDP (Kukliński, ed., 2001).

This chapter analyses the data on R\&D outlays in EU Member States including the division into the so-called "EU15" (Member States until 2004) and the so-called "EU13" (co-

\footnotetext{
${ }^{8}$ Recommendation for a Council on broad guidelines for the economic policies of the Member States and of the Union. Part I of the Europe 2020 Integrated Guidelines, $\operatorname{COM}(2010) 193\}$, Brussels, SEC(2010) 488/3.

9 Council Decision on guidelines for the employment policies of the Member States. Integrated guidelines on the Europe 2020 strategy - Part II. \{SEC (2010) 488 final.

${ }^{10}$ Communication from the Commission to the European Parliament, the Council, the European Economic and Social Committee and the Committee of the Regions. Europe 2020 Flagship Initiative. Innovation Union. Brussels, 6.10.2010, COM(2010) 546 final.
} 
untries that joined the EU in 2004 and later). In addition, the EU countries belonging to the most competitive group were examined in detail which allowed to verify the thesis that R\&D support affects economic development and competitiveness of individual countries' economies. Additionally, based on historical data, an attempt was made to estimate whether $3 \%$ of GDP expenditure on R\&D in 2020 is possible to achieve.

\subsection{EU15 and EU13 Member States}

There was in 2004 an unprecedented enlargement of the EU. It is particularly important that the EU joined countries with a much lower level of economic development measured by the GDP indicator than the EU15. In addition, in 2007 Romania and Bulgaria joined the EU. These countries differed significantly in the level of economic development from other Member States. In 2016 Croatia became a member of the EU. It seems that the EU enlargements has reduced the ability of the entire Union to achieve ambitious goals in the field of R\&D. One should also note a noticeably different level of expenditure on R\&D in relation to GDP in two groups of countries - EU15 and EU13 (except Slovenia and the Czech Republic). In this context it should be emphasized that the level of R\&D expenditure to be achieved in 2020 have varied depending on the Member State.

In order to verify the thesis regarding the possibility for individual Member States to achieve one of the goals set in the Europe 2020 Strategy related to the level of R\&D expenditure in relation to GDP an analysis was conducted focused on changes in the level of expenditure in this area in the period 2000-2016. An element of the analysis was an attempt to estimate the value of expenditure on $R \& D$ in relation to the value of GDP in each of the analysed Member States. The average annual increase in the level of expenditure on R\&D in relation to GDP in the years 2000-2016 has been calculated. The obtained results were used to extrapolate the rate of change in the examined index in the period 2017-2020 and to estimate its level at the end of 2020.

The tables below present data on the level of R\&D expenditures in the EU Member States in 2000 and 2016 and the target for a given country established for 2020 together with an indication of the deviation from the assumed target and estimates for its implementation in 2020.

The analysis of data revealed significant differences between the EU countries belonging to two groups (EU15 and EU13) with regard to the level of expenditure on R\&D in relation to GDP. The level of expenditure in the EU15 countries was much higher than the EU13 group in both 2000 and 2016. At the same time in the EU15 countries there was a decrease in the level of R\&D expenditure in relation to GDP only in Luxembourg and Finland in the analysed period. For Member States that joined the EU after 2004 the increase was identified in all countries (except Latvia, where the level of expenditure on R\&D in relation to GDP in 2000 and in 2016 was the same).

In the EU15 group the lowest level of expenditure on R\&D in relation to GDP in 2016 was recorded by Greece - it amounted to $1.0 \%$. It was higher than the level of eight out EU13 Member States. On the other hand, the higher level than in Greece was recorded in the case of Slovenia (2.0\%), the Czech Republic (1.7\%), Estonia (1.3\%) and Hungary $(1.2 \%)$. The level of expenditures in Poland in relation to GDP in 2016 was the same as in Greece. Only two of all Member States in 2016 achieved the national targets set out in the Europe 2020 Strategy for R\&D expenditure in relation to GDP. These were the Czech Republic and Cyprus. In eight EU Member States the level of R\&D expenditure in relation to 


\begin{tabular}{|c|c|c|c|c|c|c|c|c|c|c|c|c|c|c|}
\hline 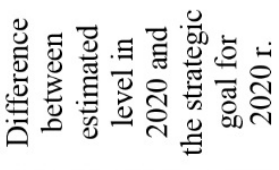 & t) & $\overrightarrow{0}$ & $\overrightarrow{0^{\circ}}$ & . & $\stackrel{\pi}{\Xi}$ & $=$ & $\hat{i}$ & $\stackrel{\sim}{\rightarrow}$ & $\mid \begin{array}{l}\overrightarrow{1} \\
\hat{\varphi}_{1}\end{array}$ & $\begin{array}{l}\vec{r} \\
\stackrel{1}{1}\end{array}$ & $\because$ & 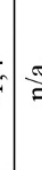 & 5 & \\
\hline 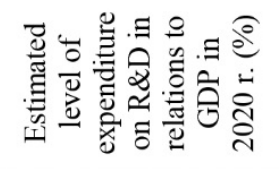 & $\begin{array}{l}0 \\
i \\
i\end{array} \mid$ & $\vec{m}$ & $\vec{m}$ & $\approx$ & $\stackrel{\pi}{\nexists}$, & 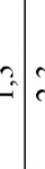 & 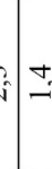 & $=$ & $\vec{i}$ & 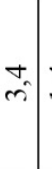 & 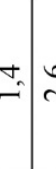 & & & \\
\hline 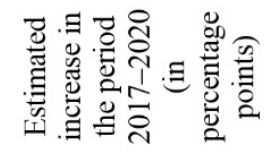 & ב̂ & ô. & $\overrightarrow{0}$ & $0_{0}$ & $\stackrel{\pi}{\Rightarrow}$ & $=$ & 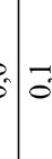 & i & $\overline{0}$ & $m_{0}$ & $\overrightarrow{0}$ & & 5 & \\
\hline 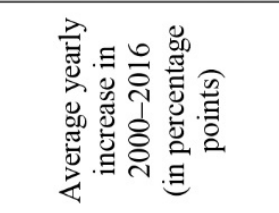 & a) & $\begin{array}{l}0 \\
0 \\
0\end{array}$ & $\begin{array}{l}\Delta \\
0_{0}\end{array}$ & $\begin{array}{l}\overrightarrow{0} \\
0^{\circ}\end{array}$ & $\stackrel{\pi}{g}$ & 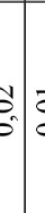 & $\delta$ & $\begin{array}{l}\tilde{\delta} \\
0 \\
0\end{array}$ & $\overrightarrow{0}$ & $\begin{array}{l}\infty \\
0 \\
0\end{array}$ & $\begin{array}{l}\tilde{U} \\
0 \\
0\end{array}$ & รี & 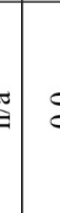 & \\
\hline 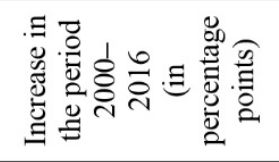 & 0 & $\hat{0}^{\circ}$ & $\because$ & $\overrightarrow{0}$ & $\stackrel{\mathbb{J}}{\beth}$ & 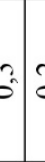 & 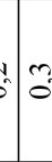 & ?. & Os & $\cong$ & 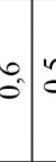 & క & $\begin{array}{c}5 \\
\end{array}$ & \\
\hline 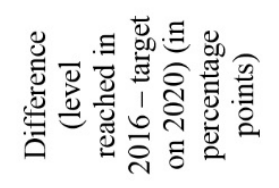 & $\mid \begin{array}{l}n \\
0 \\
1\end{array}$ & $\vec{i}$ & $\vec{i}$ & c) & 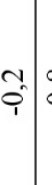 & $\begin{array}{l}0 \\
0 \\
\vdots\end{array}$ & $\begin{array}{l}0 \\
\vdots \\
\vdots\end{array}$ & $\vec{i}$ & in & $\hat{i}$ & $\begin{array}{cc}\vec{r} \\
\rightarrow\end{array}$ & 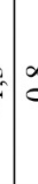 & 1) & \\
\hline 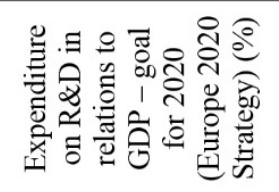 & $\stackrel{0}{m}$ & $\begin{array}{c}0 \\
m\end{array}$ & 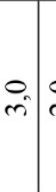 & $\hat{i}_{i}$ & $\cong$ & vil & $=$ & $\stackrel{m}{i}$ & $\begin{array}{l}n \\
i \\
i\end{array}$ & $\begin{array}{c}\infty \\
m\end{array}$ & $\hat{\mathrm{i}}$ & 9 & f & \\
\hline 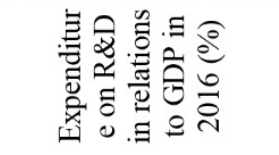 & {$\left[\begin{array}{l}n \\
i\end{array}\right]$} & $\hat{\mathrm{i}}$ & & $\approx$. & $\stackrel{0 .}{\because}$. & $=8$ & $=9$ & $\cong$ & $\stackrel{0}{i}$ & ले & $m$ & 2 & $r^{y}$ & \\
\hline 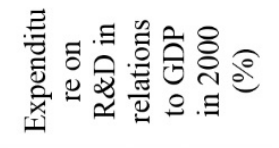 & $\approx$ & $\hat{i}$ & $\vec{i}+{ }_{i}$ & $\Rightarrow$ & $\stackrel{\pi}{\exists}$ & 8 & $\hat{i}=$ & $\stackrel{0}{-}$ & $\stackrel{\infty}{-}$ & $\Rightarrow$ & $\hat{\theta}$ & 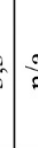 & 5 & \\
\hline 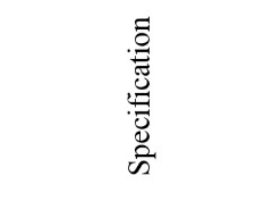 & 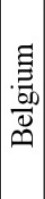 & 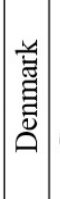 & 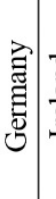 & 胥 & 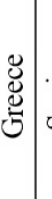 & 声 & 를 & 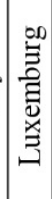 & 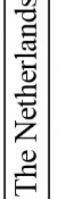 & 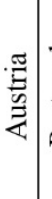 & 歌 & & & \\
\hline
\end{tabular}




\begin{tabular}{|c|c|c|c|c|c|c|c|c|c|c|c|}
\hline 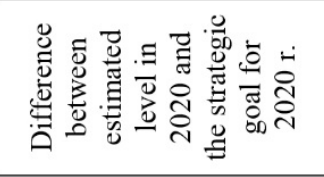 & $\left|\begin{array}{l}0 \\
0 \\
1\end{array}\right|$ & $\begin{array}{l}\infty \\
0^{0}\end{array}$ & $\begin{array}{l}n \\
\rightarrow-1\end{array}$ & $\cong 0$ & $\Rightarrow$ & $\frac{0}{1}$ & \begin{tabular}{l}
$n$ \\
\hdashline \\
$c$
\end{tabular} & $\begin{array}{l}0 \\
0 \\
0\end{array}$ & $\frac{n}{7}$ & $\mid \begin{array}{l}\infty \\
0 \\
1\end{array}$ & $\begin{array}{l}t_{0} \\
\\
\end{array}$ \\
\hline 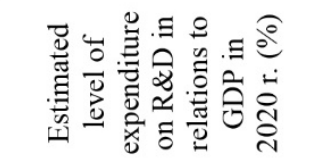 & $\begin{array}{l}\vec{o} \\
\end{array}$ & $\stackrel{\infty}{\rightarrow}$ & $\cong$ & $\stackrel{\square}{\nexists}$ & $\overrightarrow{0}^{+}$ & $\hat{\sigma}$ & $\stackrel{\Rightarrow}{\Rightarrow}$ & $=$ & $\because$ & $\begin{array}{l}n \\
\mathrm{i}\end{array}$ & $\begin{array}{l}\infty \\
0 \\
0\end{array}$ \\
\hline 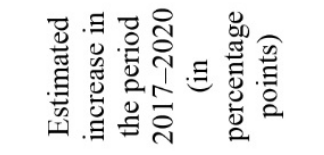 & $\overrightarrow{0}$ & $\overbrace{}^{1}$ & $\begin{array}{l}3 \\
0\end{array}$ & $\cong$ & 0 & $\overrightarrow{0}$ & $\overrightarrow{0}$ & $=0$ & $0_{0}^{\circ}$ & $\begin{array}{l}1 \\
0 \\
0\end{array}$ & $\ddot{0}$ \\
\hline 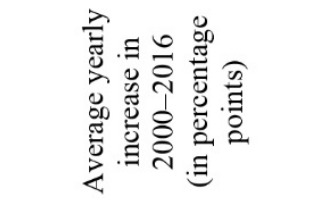 & $\begin{array}{l}\widetilde{O} \\
\delta\end{array}$ & $\begin{array}{l} \pm \\
0 \\
0\end{array}$ & $\left|\begin{array}{l}0 \\
0 \\
0\end{array}\right|$ & $\stackrel{\Xi}{\partial}$ & 8 & $\delta$ & $\stackrel{8}{0}$ & 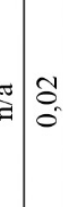 & $\overrightarrow{0}$ & $\mid \begin{array}{l} \pm \\
0 \\
0\end{array}$ & $\tilde{0}_{0}$ \\
\hline 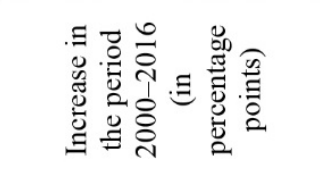 & $\begin{array}{l}m \\
0\end{array}$ & $\begin{array}{l}0 \\
0_{0}^{0}\end{array}$ & $\hat{0}$ & $\stackrel{\pi}{g}$ & $=0$ & 3 & $\stackrel{\Delta}{\circ}$ & $\begin{array}{c}5 \\
0\end{array}$ & $\overrightarrow{0}$ & $\begin{array}{l}0 \\
0^{\circ}\end{array}$ & $\mathfrak{O}_{0}$ \\
\hline 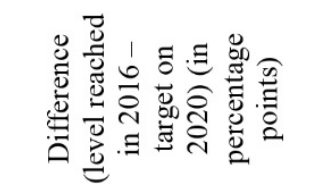 & $\hat{i}$ & $\hat{0}$ & 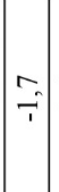 & $\stackrel{0}{:}$ & $\Rightarrow=$ & $\Rightarrow$ & \begin{tabular}{l}
0 \\
\hdashline \\
\hdashline
\end{tabular} & $\begin{array}{c}* \\
i\end{array}$ & 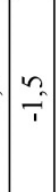 & $\mid \begin{array}{c}0 \\
-1\end{array}$ & $\begin{array}{l}\text { t. } \\
\text { în }\end{array}$ \\
\hline 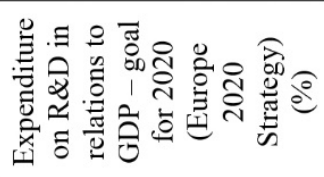 & $\stackrel{n}{-1}$ & $\stackrel{\circ}{-}$ & $\begin{array}{l}0 \\
\mathrm{~m}\end{array} \mid$ & $\stackrel{\rightarrow}{\because}:$ & 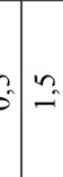 & $\therefore$ & $\stackrel{\infty}{-}=?$ & $v=$ & $\begin{array}{l}0 \\
i\end{array}$ & $\begin{array}{l}0 \\
\mathrm{~m}\end{array}$ & $\cong$ \\
\hline 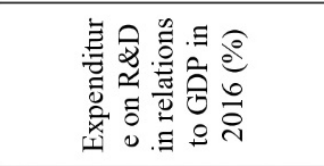 & $\left|\begin{array}{l}\infty \\
0^{\infty}\end{array}\right|$ & 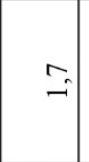 & $\stackrel{m}{\rightarrow}$ & $\begin{array}{c}\Rightarrow \\
0\end{array}$ & $\stackrel{\Delta}{0}$ & $\Leftrightarrow$ & $\cong$ & $\begin{array}{lll}0 & 0 \\
0\end{array}$ & $n$ & $\hat{i}$ & $\begin{array}{l}\infty \\
0 \\
0\end{array}$ \\
\hline 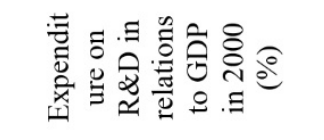 & $\left|\begin{array}{l}n \\
0\end{array}\right|$ & $\Rightarrow$ & $\because$ & $\stackrel{\pi}{3}$ & $\stackrel{\Delta}{0}$ & 0 & $\begin{array}{c}\infty \\
0 \\
0\end{array}$ & $\begin{array}{l}8 \\
z\end{array}$ & $\ddot{0}$ & $\stackrel{\oplus}{-}$ & ¿. \\
\hline 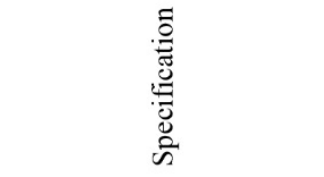 & 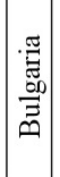 & 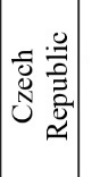 & 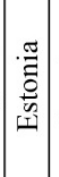 & كَّ & : & 侌 & 突 & $\begin{array}{l}\frac{3}{3} \\
\frac{3}{2}\end{array}$ & 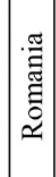 & 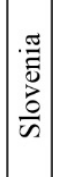 & \\
\hline
\end{tabular}


GDP in 2016 exceeded 2.5\% what is characteristic for knowledge-based economy according to the previously mentioned criterion by A. Kukliński. All of these countries belong to the EU15 group.

The analysis of the average annual changes in the level of R\&D expenditure in relation to GDP in the period 2000-2016 allowed to indicate Member States for which the national targets may be achieved. There are only 4 countries that could successfully achieve the assumed index. These include the Czech Republic, Cyprus, Denmark and Germany (for 5 countries data were unavailable). Therefore, the analysis carried out shows that the goals regarding investment in R\&D sector adopted in the Lisbon Strategy were highly unrealistic. In addition, it may lead to the conclusion that there is a significant risk of not achieving the target established in the Europe 2020 Strategy concerning level of expenditure on R\&D amounted to $3 \%$ of the EU's GDP. This scenario is realistic taking into account the fact that in 17-year-period the increase in expenditure on R\&D in the EU28 was only 0.3 percentage point and reached $2.03 \%$ of GDP in 2016.

\subsection{Expenditure on R\&D in the most competitive countries in the EU}

Referring to the global competitiveness of economies an index elaborated by the World Economic Forum was used. This institution defines competitiveness as a mutually connected set of diverse factors grouped in 12 pillars which affects the level of productivity of the country. On the other hand, the level of productivity determines the decisions about locating and starting investments in a given country. They have a positive impact on the processes of economic development ${ }^{11}$. Pillar number 12 defined by the World Economic Forum refers to the innovativeness of the economy. As emphasized by the authors of the report the innovativeness of a given economy depends on the level of expenditure on $R \& D$, both from public and private sources. Based on the 2017-2018 report the EU Member States were ranked in terms of their global competitiveness together with data referring to the level of $\mathrm{R} \& \mathrm{D}$ expenditure across GDP ${ }^{12}$.

Figure 1 presents the EU Member States ranked from the highest position in the competitiveness ranking together with the level of expenditure on the R\&D in relation to GDP recorded in 2016.

The analysis of the data presented above in the chart and in the figure leads to the conclusion indicating the relations between the level of expenditure on $R \& D$ (in relation to the GDP of the country) and the competitive position of a given economy. However, some exceptions to this rule have been identified what confirms the assumption that other factors also influence the economic competitiveness of countries (apart from the level of R\&D funding). Additional conclusions can be derived from the conducted research. The EU15 countries in comparison to EU13 are ahead of R\&D in relation to GDP and thus also in terms of competitiveness. However, some exceptions should be pointed out. Spain, Portugal, Italy and Greece have been distanced by some EU13 countries in terms of both the competitiveness ranking and the level of $R \& D$ spending. This situation may result from the fact that the economies of these countries have been most affected by the economic crisis of 2008-2009.

\footnotetext{
11 The methodology is described in detail in: (Schwab, ed., 2017).

${ }^{12}$ Data for 2016 according to Eurostat.
} 
Table 3. Ranking of EU28 countries in terms of competitiveness and corresponding expenditure on $R \& D$ in relation to GDP

\begin{tabular}{|c|c|c|}
\hline Specification & $\begin{array}{l}\text { Position in the GCI (WEF) } \\
\text { (among } 137 \text { countries) }\end{array}$ & $\begin{array}{l}\text { Expenditure on R\&D in } \\
\text { relations to GDP }(\%)\end{array}$ \\
\hline The Netherlands & 4 & 2.0 \\
\hline Germany & 5 & 2.9 \\
\hline Sweden & 7 & 3.2 \\
\hline The United Kingdom & 8 & 1.7 \\
\hline Finland & 10 & 2.8 \\
\hline Denmark & 12 & 2.9 \\
\hline Austria & 18 & 3.1 \\
\hline Luxemburg & 19 & 1.2 \\
\hline Belgium & 20 & 2.5 \\
\hline France & 22 & 2.3 \\
\hline Ireland & 24 & 1.2 \\
\hline Estonia & 29 & 1.3 \\
\hline The Czech Republic & 31 & 1.7 \\
\hline Spain & 34 & 1.2 \\
\hline Malta & 37 & 0.6 \\
\hline Poland & 39 & 1.0 \\
\hline Lithuania & 41 & 0.9 \\
\hline Portugal & 42 & 1.3 \\
\hline Italy & 43 & 1.3 \\
\hline Slovenia & 48 & 2.0 \\
\hline Bulgaria & 49 & 0.8 \\
\hline Latvia & 54 & 0.4 \\
\hline Slovakia & 59 & 0.8 \\
\hline Hungary & 60 & 1.2 \\
\hline Cyprus & 64 & 0.5 \\
\hline Romania & 68 & 0.5 \\
\hline Croatia & 74 & 0.9 \\
\hline Greece & 87 & 1.0 \\
\hline
\end{tabular}

Source: Own elaboration based on Global Competitiveness Report 2017-2018 and Eurostat data for 2016.

The analysis of the competitiveness ranking of the World Economic Forum revealed that as many as five EU15 countries are in the top ten of the most competitive countries in the world. The first EU13 country is 29th in the ranking (Estonia). This indicates, on the one hand, the persistent diversification in the economic environment between the EU15 and EU13 and on the other the large divergence within these two groups. 


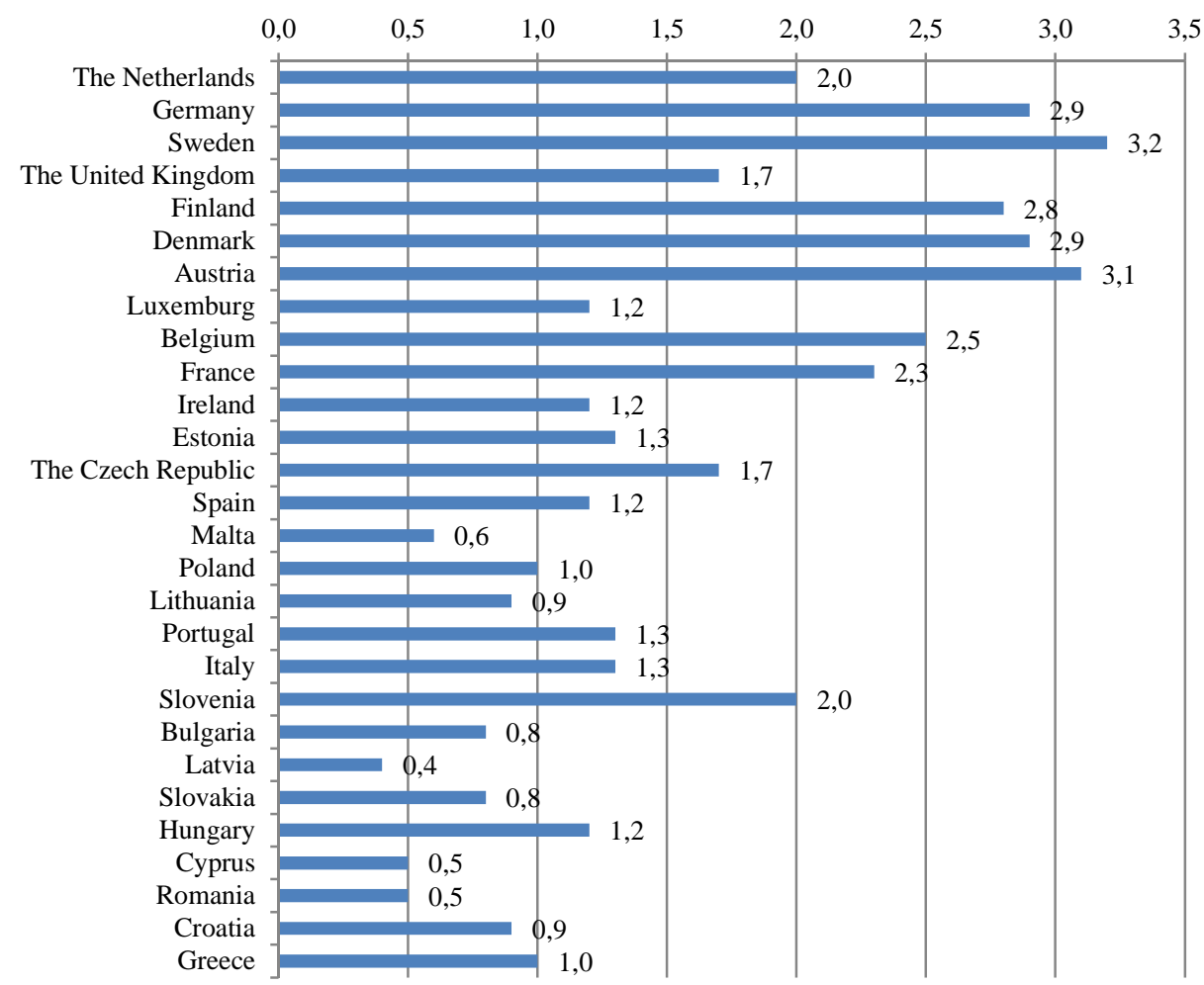

Figure 1. Expenditure on R\&D in relation to GDP (countries ranked from the most competitive according to the Global Competitiveness Report 2017-2018) (\%)

Source: Own study based on Global Competitiveness Report 2015-2016 and Eurostat data for 2016.

\subsection{Structure of financing expenditure on $R \& D$ (state budget and private sector expenditure)}

The optimal model for financing R\&D which has a positive impact on the entire economy is dominance of the private sector in this field. It brings about additional advantage: the results of research and development are implemented in the economy practise in the form of, for example, new innovative technologies. This combination of the science and business results in added value to the economy. The figure below presents a comparison of the share of financing R\&D expenditure from public and private sources with regard to the entire financing of the $R \& D$ of individual countries.

Data analysis allows to formulate the following conclusions regarding the financing of R\&D expenditure in the European Union. For 18 countries the private sector played a dominant role in financing $R \& D$ spending. The majority countries in which the public sector was the main source of financing R\&D joined the EU in 2004 and later. From the EU15 countries in this group were Portugal, Luxembourg and Greece. Portugal and Greece are the countries that were significantly affected by the negative effects of the economic crisis 
of 2008-2009. These results provide the basis for the conclusion that state activity in stimulating factors of socio-economic development, such as investments in R\&D is noticeable in countries with less developed economies. The structure of investing R\&D sector is changing in favour of private investors in more developed economies.

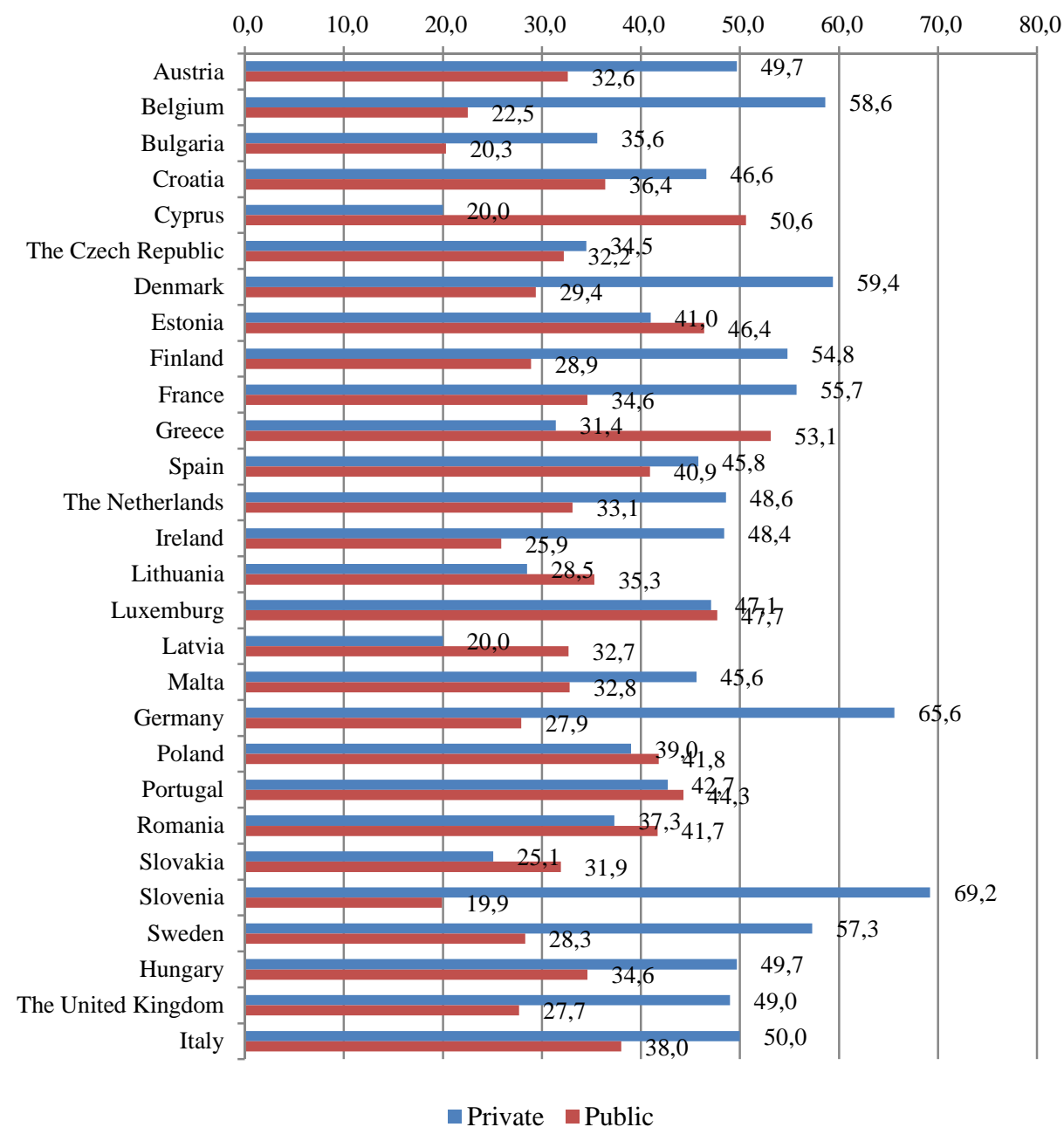

Figure 2. Summary of the share of $R \& D$ expenditure financing from public and private sources in total R\&D expenditure in the EU28 countries in 2015* (\%)

* data for France for 2014, data for Sweden (public spending) for 2013

Source: Own elaboration based on Eurostat data [Access: 30.07.2018]. Access on the internet: $\mathrm{http} / / /$ ec.europa.eu/eurostat/web/science-technology-innovation/data/database. 


\section{FINAL CONCLUSIONS}

Simplified analysis of statistical data on financing of R\&D in the European Union countries allows to verify common opinions on the role of this sphere in the development of global competitiveness of the EU and its individual Member States. First of all, it should be emphasized that the significant importance of the EU research and development policy sanctioned by relevant provisions in the most important EU documents is rather poorly reflected in the level of financing of R\&D in individual Member States. In 2016 this level was for the EU28 - 2.03\% of GDP (and thus significantly deviated from the assumed 3.0\% in both the Lisbon Strategy and the Europe 2020 Strategy). However, there is a weak but systematic increase in the level of financing these expenditures in the entire EU28.

Secondly, the analysis of the dynamics of changes in the level of financing R\&D in the EU28 and in individual Member States clearly indicates that it is doubtful that the objective of the level of financing for this sphere in 2020 set out in the Europe 2020 Strategy will be achieved.

Thirdly, the share of financing R\&D from private sources is systematically increasing in relation to the share of expenditure from public sources. The economic crisis has not changed this phenomenon which gives grounds for conclusion that $R \& D$ is actually perceived by private entities (companies) as a factor of success for their development. In addition, it can be assumed that there is increasingly strong link between the R\&D sphere (science) and business which should result in further improvement of micro- and macroscale competitiveness and further development of R\&D activities.

Fourthly, the analysis of statistical data indicates a positive correlation between expenditure on R\&D in relation to GDP in a given country and the competitive position of economies - the higher the level of financing expenditure on R\&D the more competitive economy.

Summing up, it can be concluded that the R\&D sphere is perceived by the EU countries as a source of economic growth and competitiveness (EU official documents). However, weak dynamics of growth in outlays on this sphere may result in failure to achieve the assumed indicators and thus worsen the competitive position of the EU countries in the global world. There is still space for substantial changes including the increase in level of expenditure on R\&D to avoid this pessimistic scenario.

\section{REFERENCES}

Aghion, P. (2006). A primer on innovation and growth. Brussles: Bruegel Policy Brief. Council Decision on guidelines for the employment policies of the Member States. Integrated guidelines on the Europe 2020 strategy - Part II. \{SEC (2010) 488 final .

Commission staff working document. Lisbon Strategy evaluation document, Brussels, 02.02.2010, SEC (2010), 114, final.

Ferrer, J.N., Figueira, F. (2011). Achieving Europe's R\&D Objectives. Delivery tools and role for the EU budget. Stockholm: SIEPS.

Kukliński, A., red. (2001). Gospodarka oparta na wiedzy jako wyzwanie dla Polski XXI wieku. Warszawa: KBN.

Communication from the Commission to the European Parliament, the Council, the European Economic and Social Committee and the Committee of the Regions. Europe 2020 Flagship Initiative. Innovation Union. Brussels, 6.10.2010, COM(2010) 546 final

Klamut, M., red. (1999). Konkurencyjność regionów. Wrocław: Wyd. AE we Wrocławiu. 
Kupchan, Ch. (2011). Stanów Zjednoczonych Europy nie będzie. „Rzeczpospolita” z 6.12.2011 [Access: 1.05.2012]. Access on the internet: http://www.rp.pl/artykul/765377.html.

Żukrowska, K., red. (2008). Nauki ekonomiczno-spoteczne i rozwój. Warszawa: Oficyna Wydawnicza SGH.

Węcławski, J., red. (2005). Nauki ekonomiczne wobec problemów współczesnej gospodarki. Lublin: Wyd. UMCS.

Prusek, A., red. (2010). Nauki ekonomiczne wobec wyzwań wspótczesnej gospodarki światowej. Kraków: Wyd. UE w Krakowie.

Communication from the Commission, Europe 2020. A strategy for smart, sustainable and inclusive growth, Brussels, 3.3.2010, COM(2010) 2020 final

Schwab, K., ed. (2011). The Global Competitiveness Report 2011-2012. Geneva: World Economic Forum.

Torreblanca, J.I. (2012). Rok 2012 rokiem proroczym, „El Pais”. Access on the internet: http://www.presseurop.eu/pl/content/article/1347331-rok-2012-rokiem-proroczym (01.05.2012)

Recommendation for a Council on broad guidelines for the economic policies of the Member States and of the Union. Part I of the Europe 2020 Integrated Guidelines, COM(2010) 193\}, Brussels, SEC(2010) 488/3

Nowakowska, A., red. (2009). Zdolności innowacyjne polskich regionów. Łódź: Wyd. Biblioteka.

DOI: 10.7862/rz.2019.mmr.10

The text was submitted to the editorial office: April 2019.

The text was accepted for publication: June 2019. 
